\title{
QUE CONSEQUÊNCIAS TEM O USO EXCESSIVO DE CELULAR PARA A FORMAÇÁO JURÍDICA?
}

\author{
Edmilson de Jesus Ferreira ${ }^{1}$ \\ Escola Superior Dom Helder Câmara (ESDHC) \\ Adair José dos Santos Rocha ${ }^{2}$ \\ Escola Superior Dom Helder Câmara (ESDHC) \\ Cláudia Madrona Moreira Haas ${ }^{3}$ \\ Escola Superior Dom Helder Câmara (ESDHC) \\ Artigo recebido em: 12/11/2019. \\ Artigo aceito em: 05/12/2019.
}

\section{Resumo}

$\mathrm{O}$ presente artigo tem como objetivo refletir sobre as consequências do uso diário do celular e o tempo de estudo pessoal para a formação jurídica dos estudantes, a partir da experiência de sala de aula com calouros de Direito da Escola Superior Dom Helder Câmara do $1^{\circ}$ semestre de 2019. A metodologia aplicada foi o levantamento, utilizando a técnica do Questionário na coleta dos dados. O recorte é quali-quantitativo, detendo-se sobre o tempo gasto mexendo no celular e no estudo pessoal pelos estudantes. Os conceitos de importância da Tríade do Tempo de Christian Barbosa e de interferência e interferência de objetivo de Adam Gaz-

zeley e Lary Rosen foram os referenciais teóricos básicos. Os resultados mostram uma maior média de tempo gasto mexendo no celular do que a média dedicada ao tempo de estudo pessoal; evidenciam que o tempo dedicado ao estudo pessoal é inversamente proporcional ao tempo mexendo no celular; e que os alunos que dedicavam mais tempo ao estudo pessoal diário gastavam no máximo $2 \mathrm{~h} 30 \mathrm{~min}$ mexendo no celular.

Palavras-chave: celular; formação jurídica; gestão do tempo; tempo de estudo pessoal.

\footnotetext{
1 Mestre em Direito Ambiental pela ESDHC. Bacharel em Direito pela ESDHC. Bacharel em Filosofia pela Filosofia pela Faculdade Jesuíta de Filosofia e Teologia (FAJE). Professor da graduaçấo em Direito na ESDHC. Professor da graduaçăo em Engenharia Civil da Escola de Engenharia de Minas Gerais (EMGE). Coordenador de Ensino a Distânca da ESDHC. ORCID: https://orcid.org/0000-0002-6303-297X/e-mail: edjfer@gmail.com

2 Mestrado em Educação pela Universidade Federal de Minas Gerais (UFMG). Graduado em Filosofia pela Faculdade Jesuíta de Filosofia e Teologia (FAJE). Graduado em Pedagogia Orientação Educacional pela Faculdade Estadual de Ciências e Letras de Campo Mourão (FECILCAM). ORCID: https://orcid.org/0000-0001-6582-376X/e-mail: adair.jose@domhelder.edu.br

3 Graduada em Psicologia pela Pontifícia Universidade Católica de Minas Gerais (PUC-MINAS). Psicóloga na ESDHC. E-mail: cmmhaas@yahoo.com.br
} 


\section{WHAT CONSEQUENCES HAS EXCESSIVE CELL PHONE USE FOR LEGAL EDUCATION?}

\section{Abstract}

This article aims to think over the consequences of daily mobile phone use and personal study time for students' legal education, from the classroom experience with the beginner students from the Dom Helder Camara Higher School of the 1st semester of 2019. The methodology applied was the survey, using the Questionnaire technique in the data collection. The focus is qualitative and quantitative by emphasizing the time spent by students handling cell phones and personal study. The concepts of importance of Christian Barbosa's Triad of Time and the concepts of interference and goal interference by

Adam Gazzeley and Lary Rosen were the basic theoretical frameworks. The results show a higher average of time spent handling the cell phone than the average dedicated to personal study time; they show that the time dedicated to personal study is inversely proportional to the time spent on the cell phone; that students who dedicated more time to daily personal study spent a maximum of $2 \mathrm{~h} 30 \mathrm{~min}$ handling their cell phones.

Keywords: cell phone; legal education; personal study time; time management. 


\section{Introdução}

O objetivo deste artigo é refletir sobre as consequências do uso diário excessivo do celular e o tempo de estudo pessoal para a formaçáa jurídica dos estudantes. Para tanto, partimos de uma experiência com os estudantes de Direito do primeiro período de Direito da Escola Superior Dom Helder Câmara do primeiro semestre de 2019. O problema subjacente foi "Que consequências o uso diário excessivo do celular provoca sobre o tempo de estudo dos calouros do Direito?”. Usamos como referencial teórico básico o conceito de importância da Tríade do Tempo de Christian Barbosa, edição de 2008, e os conceitos de interferência e interferência de objetivo (GAZZELEY; ROSEN, 2016). O tempo dedicado ao estudo pessoal, fora da sala de aula é uma atividade importante para os estudantes porque contribui para a formação de profissionais qualificados em diferentes áreas, a formação de pesquisadores e a formação de cidadãos críticos. Portanto, compreender se o uso excessivo do celular diminui o tempo com essa atividade é primordial. Partimos de duas pressuposiçôes básicas: (1) o tempo dedicado ao estudo é uma atividade importante (BARBOSA, 2008; ROCHA; HAAS, 2018) porque contribui para a formação de profissionais qualificados em diferentes áreas, pesquisadores e cidadáos críticos (SEVERINO, 2010); e (2) o uso excessivo do celular é uma atividade circunstancial que diminui o tempo que os estudantes dedicam ao estudo pessoal.

\section{Os objetivos do ensino superior brasileiro e a formação jurídica}

Os objetivos do ensino superior brasileiro estão estabelecidos no art. 43 da Lei de Diretrizes e Bases da Educação Nacional (LDBN) ${ }^{4}$ de 1996. Fundamentada na Constituição de $1988^{5}$ (CF 88), ela estabelece as diretrizes e bases da educação nacional. Carneiro (2015) a considera o GPS e a bússola da educação brasileira. No art. $2^{\circ}$, a LDB prescreve três finalidades da educação nacional: pleno desenvolvimento do educando, preparo para o exercício da cidadania e qualificação para o trabalho. Os objetivos específicos do ensino superior estão em oito incisos do art. $43^{6}$. Em síntese, são: (1) estímulo à criação cultural e o "desenvolvimento científico"; (2) formação de profissionais nas diferentes áreas de conhecimento; (3) incentivo à pesquisa científica; (4) "divulgação de conhecimentos culturais,

4 A atual LDBN é a Lei n. 9.394, de 20 de dezembro de 1996. Disponível em: http://www.planalto.gov.br/ccivil_03/ leis/19394.htm. Acesso em: 28 out. 2019. Para simplificar, vamos abreviar LDBN por LDB.

5 A Constituiçăo Federal de 1988 tratou da educação nos arts. 205 a 214.

6 A LDB e o art. 43 em sua literalidade. Disponível em: http://www.planalto.gov.br/ccivil_03/leis/19394.htm. Acesso em: 25 set. 2019. 
científicos e técnicos"; (5) motivação do aperfeiçoamento cultural e profissional; (6) estímulo ao conhecimento dos problemas da realidade e prestaçáo de serviços à comunidade; (7) promoção da extensão como modo de difusão do conhecimento produzido pela instituição de educação superior (IES); e (8) ação em favor da universalização e do aprimoramento da educação básica (BRASIL, 1996). Este último e importante inciso foi inserido pela Lei n. 13.174, de 2015.

A formação jurídica atual está delineada na Resolução n. 5 de 17 de dezembro de 2018 do Conselho Nacional de Educação. Ela instituiu as Diretrizes Curriculares Nacionais do curso de graduação em Direito. $\mathrm{O}$ art. $5^{\circ}$ estabelece que a perspectiva formativa deve contemplar formação geral, técnico-jurídica e prático-profissional, mantendo como prioridade a interdisciplinaridade e articulação de saberes. O perfil do graduando é fixado pelo art. $3^{\circ}$ :

O curso de graduação em Direito deverá assegurar, no perfil do graduando, sólida formação geral, humanística, capacidade de análise, domínio de conceitos e da terminologia jurídica, capacidade de argumentação, interpretação e valorização dos fenômenos jurídicos e sociais, além do domínio das formas consensuais de composição de conflitos, aliado a uma postura reflexiva e de visão crítica que fomente a capacidade e a aptidão para a aprendizagem, autônoma e dinâmica, indispensável ao exercício do Direito, à prestaçấo da justiça e ao desenvolvimento da cidadania (BRASIL, 2018, p. 2).

Percebe-se que o objetivo definido pelo "assegurar" para a formação jurídica é bastante abrangente para abarcar as três perspectivas formativas do art. $5^{\circ}$. A formação profissional, tratada no art. $4^{\circ}$, define o rol de competências cognitivas, instrumentais e interpessoais que o graduando deve adquirir. Mesmo assim, tendo em vista os avanços tecnológicos do século XXI e seus impactos tecnológicos na área jurídica, Sales e Bezerra (2018) sugerem a necessidade de revisão das habilidades jurídicas atuais e a formação deve estimular novas competências e habilidades requeridas.

\section{A formação humanística do jurista no século XXI}

Tendo em vista a abrangência da formação jurídica proposta na resolução e os desafios tecnológicos do século XXI, é necessária uma ênfase na formação humanística. A despeito da enorme capacidade humana de adaptaçáo, podemos perceber que o colossal avanço tecnológico, que desemboca em uma descomunal avalanche de produtos tecnológicos e culturais, bem como em um 
volume de informaçóes praticamente "improcessável" pela mente humana, não necessariamente significa evolução humana. É impossível que consigamos acessar e manusear adequadamente tudo isso, gerando conhecimento seja científico, técnico ou prático. Prático, nesse contexto, refere-se ao sentido ético, isto é, diz respeito ao agir propriamente humano que envolve reflexão, deliberação, discernimento como faculdade de julgar (distinguir), escolher, decidir e, por fim, agir.

Nesse ínterim, torna-se imperioso abordarmos alguns conceitos muito importantes que nos legou Aristóteles, tais como "fim", "bem", "meio-termo", "atividade da alma", "excelência" e "felicidade". Entre eles há uma relação muito estreita e todos fazem parte do processo de educação do caráter do indivíduo, do cidadáo. A ideia de fim tem sua raiz na palavra grega telos, que carrega em sua carga semântica o sentido de finalidade, propósito, objetivo, meta. Isso evoca a ideia de algo a ser buscado e encontrado para dar verdadeiro sentido a todo o ser e, especialmente na perspectiva aqui abordada, a toda circunstância e atitude. Na compreensão de Aristóteles (2009, p. 17), "o bem é aquilo por que tudo anseia”, isto é, tudo tem um fim próprio, e este é, por conseguinte, seu bem próprio. Portanto, para ele, tudo e toda circunstância ou ação tem um bem a ser buscado e atingido e o bem, nesse sentido, é aquilo que é próprio a cada coisa, circunstância ou ação. Descobrir esse bem e agir conforme ele não é naturalmente dado, exige esforço racional e volitivo. Para Aristóteles, o hábito de buscarmos a maneira mais apropriada de agirmos é que molda nosso caráter, levando-nos à excelência. Alcançar o bem e, portanto, a felicidade, envolve comprometimento físico e racional do indivíduo. Em suas palavras, trata-se de energeia, uma atividade da alma, pela qual se encontra o que é mais adequado a cada situação e, assim, atinge-se o estado de felicidade, autorrealização.

Mas o que isso tem a ver com nosso estudo sobre o uso do aparelho celular, gerenciamento de tempo de estudo e aproveitamento acadêmico? Se concordamos com Aristóteles de que cada situação e ação têm uma finalidade e, portanto, um bem a ser alcançado que nos levará a algum resultado (aproveitamento), então resta claro que necessitamos constantemente estar atentos para refletir sobre como lidamos com as coisas que possuímos, as circunstâncias que nos afetam e as escolhas que fazemos. Quando nos deixamos levar pelas circunstâncias sociais, tecnológicas, culturais ou pessoais de maneira irrefletida, desembocamos no desequilíbrio e prejudicamos nosso desenvolvimento, nossa capacidade produtiva e nosso desempenho acadêmico. Nessa perspectiva, Aristóteles (2009) evidencia que em matéria de ação humana, a excelência não consiste no conhecer teórica, cognitiva ou cientificamente, mas no agir concreto como capacidade de, habitualmente, em cada situação, refletir, decidir e agir racionalmente, tendo 
encontrado o modo mais apropriado. Do contrário, quando estamos muito habituados a agir de maneira equivocada, segundo Aristóteles $(2009)^{7}$, não basta apenas discursos para a mudança de comportamento. É necessário um grande esforço e engajamento para a mudança. Isso implica ter clareza do que se deseja realmente, isto é, objetivos claros, o que, no caso do(a) estudante diz respeito à excelência em sua aprendizagem, ao magis da pedagogia inaciana.

As referidas matérias a que ele aduz dizem respeito à formação do caráter a partir do exercício das diversas virtudes que se expressam pelo chamado justo meio (mesotés), o devido meio-termo, equilíbrio, entre o excesso e a carência. Para esse processo, quando o indivíduo, no caso do jovem, por exemplo, por si só, não é apto, é necessário ser instruído por "leis" que os ajudem a se habituarem a agir virtuosamente na prática. Aqui, adequadamente adaptado a nosso contexto, não se trataria da criação de codificar tudo, mas de criar processos de educação capazes de gerar reflexão e mudança de condutas, tendo em vista os objetivos da educação antes referidos de acordo com a LDB. A questáo central aqui é: como fazer os(as) estudantes, jovens altamente habituados ao uso, quase que em tempo integral, de equipamentos eletrônicos variados, sobretudo celulares, gerenciarem melhor seus hábitos e direcionar, durante seu processo de formação acadêmica, seu potencial intelectual efetivamente para o processo de aprendizagem com excelência? Que espaços e instrumentais de reflexáo estamos oferecendo a eles?

Neste ponto, vale destacar a importância que o autor dá para a força da influência e dos hábitos familiares. Precisamos ter muito cuidado com as maneiras de agir que, às vezes, até mesmo inconscientemente, vamos introduzindo em nosso modo de agir e em nossos comportamentos. Há estudos que mostram que diversos hábitos que temos desenvolvido têm acarretado sérios problemas de saúde tanto física como mental e ética com reflexos diretos na qualidade de nossos relacionamentos. Precisamos estar atentos para buscarmos hábitos saudáveis a fim de cultivarmos relaçóes e comportamentos mais saudáveis, seja no âmbito familiar, acadêmico ou profissional.

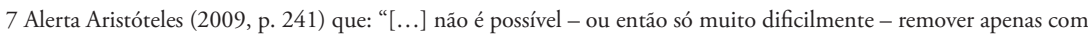
discurso disposiçóes há já muito tempo alojadas [...] o que vive exposto à paixão năo é capaz de ouvir a palavra que o tenta desviar do seu caminho e [mesmo que a ouça] não conseguirá entendê-la. Como poderá mudar-se a maneira de sentir daquele que assim vive?". 


\section{A ascensão do celular no século XXI como um fenômeno global}

Nesse cenário, aprender a lidar bem com o celular tornou-se uma necessidade do século XXI. Segundo o Relatório da União Internacional das Telecomunicaçóes (ITU), houve aumento gradativo na aquisição de aparelhos celulares no mundo inteiro e a queda no preço deles. Esse aparelho tornou-se o responsável pelo declínio da telefonia fixa. Ele trouxe grande flexibilidade ao possibilitar que as pessoas acessem e sejam acessadas individualmente em qualquer lugar. Constatou-se, ainda, que a quantidade de assinaturas de celular, de banda larga móvel e acesso à internet cresceram no mundo inteiro de 2005 a 2018. As assinaturas de banda larga móvel saltaram de 268 milhóes em 2007 para 5,3 bilhóes em 2018 (ITU, 2018). No Brasil, a pesquisa do Instituto Brasileiro de Geografia e Estatística (IBGE) mostra o acesso de várias camadas sociais ${ }^{8}$ ao celular, inclusive pessoas na condição de estudante (IBGE, 2007, 2015, 2018a, 2018b). A população estudantil que tinha celular, em 2005 , era $35 \%$ e subiu para $46,5 \%$ em 2011, 69,9\% em 2013, 73,6\% em 2014 (IBGE, 2007; 2015; 2016).

Atualmente, percebe-se uma convergência de várias atividades da era digital (acesso à internet, mensagem de voz, envio de imagens, fotos etc.) para o celular (IBGE, 2007; 2015; 2018a: 2018b). O celular se tornou a principal ferramenta de acesso à internet e às redes sociais ${ }^{10}$ (WE ARE SOCIAL; HOOTSUITE, 2019). No Brasil ${ }^{11}$, o acesso via celular é de $94,6 \%$, substituindo o computador $(63,7 \%)$

8 Isso fica evidenciado pela pesquisa Acesso à Internet e Telefone móvel celular para uso pessoal, realizada pelo Instituto Brasileiro de Geografia e Estatística (IBGE) a partir de 2005. Em 2005, 36,7\% da população brasileira de 10 anos ou mais possuía celular móvel. O maior índice de posse de celular era da população ocupada (44,4\%) (IBGE, 2007). O percentual de possuidores de celular saltou para 53,7\% (2008), 57,6\% (2009), 69,01\% (2011), 91,1\%, em 2014 (IBGE, 2007, 2015, 2016). Em 2011, 86,4\% dos domicílios brasileiros já contavam com celular móvel. O percentual entre os trabalhadores subiu para 69,1\% (IBGE, 2015). Em 2013, uma mudança no modo de acessar à internet foi identificado pela pesquisa. Surgiu o conceito "utilizaçấo de Internet somente por meio de outros equipamentos", que incluía o celular móvel. A nota explicativa do Gráfico 6 do documento informava: "(1) A investigação da utilização da internet, que antes abrangia somente o microcomputador, passou a contemplar qualquer equipamento (microcomputador, telefone móvel celular, tablet ou outro)". O celular assumiu $53,6 \%$ do acesso à internet nos domicílios e 75,2\% da população possuía celular (IBGE, 2015). O acesso à internet nos domicílios via celular subiu para 80,4\%. A utilização por meio de outros equipamentos saltou de 3,6\% (2013) para 8,6\% (2014). Enquanto o celular ascendia, o uso do computador diminuía (IBGE, 2016).

9 O Relatório Digital 2019: Brasil mostra que mais de 215 milhốes de assinatura de celular e que 89\% da população brasileira possui algum tipo de celular (WE ARE SOCIAL; HOOTSUITE, 2019). Possuía 140 milhôes de usuários ativos de mídias sociais (redes sociais etc.) e 130 milhóes de usuários de mídias sociais via celular (61\% da populaçăo).

10 O que são redes sociais? Para Kaplan e Haenlein (2010, p. 61) é: "um grupo de aplicativos baseados na internet desenvolvidos a partir das bases ideológicas e tecnológicas da WEB 2.0 e que permitem a criação e troca de conteúdo gerado por usuários." Em 2019, Facebook e YouTube agregam mais de 4 bilhôes de usuários (WE ARE SOCIAL; HOOTSUITE, 2019).

11 As estatísticas globais de tempo gasto com internet e celular permitem comparar a média do Brasil e do mundo. A média global de tempo diário acessando internet é $6 \mathrm{~h} 42 \mathrm{~min}$ e a média do Brasil é $9 \mathrm{~h} 29 \mathrm{~min}$ (WE ARE SOCIAL; HOOTSUITE, 2019). A média global de acesso via celular é $3 \mathrm{~h} 14 \mathrm{~min}$, porém, a média brasileira é $4 \mathrm{~h} 45 \mathrm{~min}$. Os dados mostram que, em média, 27,9\% da vida diária de 4.388 bilhóes de pessoas (usuários de 
(IBGE, 2018a: 2018b). As quatro principais finalidades do acesso à internet são: 1) "enviar ou receber mensagens de texto, voz ou imagens por aplicativos diferentes de e-mail" (94,2\%); 2) "assistir a vídeos, inclusive programas, séries e filme" (76,4\%); 3) "conversar por chamadas de voz ou vídeo" (73,3\%); 4) "enviar ou receber e-mail” (69,3\%) (IBGE, 2018b).

Mas por que não usar o celular e as redes sociais como ferramentas para melhorar o estudo e a aprendizagem? O uso de celular e redes sociais como ferramentas educativas tem sido problemático com defensores e detratores de ambos os lados. Há estudos demonstrando efeitos nocivos para os usuários. Mas quais são os efeitos desta exposição excessiva das pessoas ao celular?

\subsection{A mente distraída pelo celular}

A mente distraída é um efeito da exposição constante e crescente ao celular. O fenômeno foi analisado no livro The Distracted Mind pelo psiquiatra Adam Gazzaley e pelo psicólogo Larry Rosen. Eles usaram os conceitos de "interferência" e "interferência de objetivo". Gazzaley e Rosen (2016, p. 5) definem interferência como "um termo geral usado para descrever algo que dificulta, obstrui, impede ou desencaminha ${ }^{12}$ amplamente outro processo". Ela pode ser causada por distraçóes (informaçóes irrelevantes) ou interrupções (tentar perseguir simultaneamente vários objetivos). As interrupçôes são chamadas de multitarefas. Além disso, as distraçóes e as interrupçôes podem ser internas (pensamentos na mente) ou externas (estímulos sensoriais, como conversas, bipes, vibraçôes ou exibiçôes visuais intermitentes). A interferência de objetivo" ${ }^{13}$ (meta) "ocorre quando você toma uma decisão de atingir uma meta específica (por exemplo, buscar algo da geladeira, concluir uma tarefa de trabalho, iniciar uma conversa, dirigir seu carro) e algo acontece para impedir a conclusão bem-sucedida dessa meta" (GAZZALEY; ROSEN, 2016, p. 5). Os conceitos de "interferência" (distrações e interrupçóes) e "interferência de objetivo" são muito úteis para compreender o impacto gerado pelo celular sobre seus usuários.

No âmbito acadêmico, estudos demonstram um impacto negativo do uso excessivo de telefones celulares sobre o desempenho acadêmico de estudantes

internet) é gasta on-line, uma vez que 13,4\% desse total é acessando via celular. Os brasileiros gastam, em média, $39,5 \%$ de suas vidas na rede e $19,7 \%$ desse tempo é via celular.

12 No original em inglês: "is a general term used to describe something that hinders, obstructs, impedes, or largely derails another process" (GAZZALE; ROSEN, 2016, p. 5). O verbo "derails" literalmente significa "descarilhar", ou seja, sair dos trilhos. Preferimos traduzir por "desencaminha” como fazer sair do caminho pretendido.

13 No original em inglês: "Goal interference occurs when you reach a decision to accomplish a specific goal (e.g., retrieve something from the refrigerator, complete a work assignment, engage in a conversation, drive your car) and something takes place to hinder the successful completion of that goal" (GAZZALEY; ROSEN, 2016, p. 5). Preferimos traduzir "goal interference" por "interferência de objetivo", mas poderia ser "interferência de meta". 
universitários. Lepp, Barkley e Karpinsky (2015) afirmaram que o celular se integrou à vida e ao ambiente acadêmico mesmo durante o horário de aula, mas concluíram que o uso excessivo impacta negativamente ${ }^{14}$ na média geral dos estudantes. Twenge (2018) identificou um declínio no tempo dedicado às tarefas escolares entre os adolescentes americanos de 2012 a 2015 e relaciona esse declínio ao aumento do uso do smartphone. Outro estudioso, Bernard McCoy (2015), descobriu que aproximadamente $97 \%$ dos estudantes usam o celular em sala de aula para objetivos não educacionais ${ }^{15}$, como verificar e-mail (75\%), acessar mídias sociais $(70 \%)$, navegar na internet (40\%) e jogar (10\%). Portanto, o uso de celular tem aumentado o gasto de tempo dos estudantes com entretenimento, mesmo em sala de aula e, consequentemente, diminuído o tempo diário de estudo dos acadêmicos. Assim, em tempos de celular acessível a todos, a gestão do tempo ${ }^{16}$ pode ser a habilidade mais importante para um estudante.

\subsection{A necessidade da gestáo de tempo no mundo dominado pelo celular}

Barbosa (2008) propõe uma metodologia (modelo) de gestão do tempo baseada nos conceitos de importância, urgência e circunstância (Tríade do Tempo). Todas as atividades podem ser classificadas nessas três categorias. Atividades importantes são aquelas que produzem resultados na vida acadêmica, pessoal e profissional. Atividades urgentes são aquelas em que o tempo hábil acabou e, por isso, são feitas sob pressão e estresse. Atividades circunstanciais são as que não geram resultado algum e, por isso, são uma perda de tempo (BARBOSA, 2008).

Rocha e Haas (2018) usaram essa metodologia para interpretar como calouros de Direito geriam seu tempo. Concluíram que a má gestão dos estudantes se caracterizava pelo pouco tempo dedicado às atividades importantes (ROCHA;

14 Depois de controlar os preditores de desempenho escolar preestabelecidos, o uso de celular foi apontado como um preditor negativo significativo da GPA. Tal resultado sugere que, dados dois estudantes universitários da mesma universidade, com a mesma frequência em sala de aula, o mesmo gênero, o mesmo comportamento tabagista, a mesma crença em sua capacidade de autorregular sua aprendizagem e ser bem-sucedidos academicamente e o mesmo GPA alto na escola, aquele que utiliza o celular com maior frequência diariamente é mais suscetível a apresentar um GPA mais baixo que o aluno que faz uso do celular com menor frequência (LEPP; BARKLEY; KARPINSKY, 2015). 15 Sobre o uso de internet para propósitos não educacionais em sala de aula, vale a pena consultar as pesquisas de Ravizza, Hambrick e Fenn (2014), que afirmam que mesmo os melhores estudantes sofrem prejuízo pelo uso de internet e celular por propósitos náo educacionais em sala de aula. Ravizza, Uitvlugt e Fenn (2016), por sua vez, comprovou que, durante aulas de 100 minutos, os estudantes gastaram 52\% do tempo com finalidades nẩo acadêmicas. Os principais usos foram mídia social, e-mail, compras, vídeos, bate-papo, leitura de notícias e jogos.

16 Boyd e Zimbardo (2009) apontaram um importante aspecto econômico do tempo. Segundo os autores, o tempo é valioso não por equivaler ao pensamento "tempo é dinheiro", mas sim porque é o bem mais escasso no mundo. Portanto, o tempo é mais valioso do que o dinheiro. Sendo assim, e considerando que as pessoas são racionais, é de se esperar que usem racionalmente e com certo equilíbrio o tempo diário em atividades importantes como dormir, comer, trabalhar, estudar, cuidar do bem-estar físico e mental etc. 
HAAS, 2018). Gonçalves et al. (2015) analisaram a "influência do tempo de estudo no rendimento do aluno universitário" de Direito e concluíram que o tempo semanal dedicado às atividades extraclasse (estudo pessoal) influenciou $36 \%$ do rendimento acadêmico dos alunos do primeiro período.

\section{A experiência do inventário pessoal do tempo}

Durante as aulas de Metodologia dos Estudos e Gestão do Tempo da disciplina Proficiência Acadêmica, para melhorar a gestão do tempo, foi proposto o experimento ${ }^{17}$ "Inventário Pessoal do Tempo" na forma de atividade avaliativa. O objetivo era descobrir quanto tempo dedicavam a cada tipo de atividade diária. Os(as) estudantes foram instruídos(as) sobre como realizar o experimento de observação durante um dia. As instruçóes, explicadas em sala de aula e postadas, em Powerpoint ${ }^{\circ}$, na respectiva aula no Portal Acadêmico, foram as seguintes: (1) escolha um dia mais comum de sua rotina; (2) observe quanto tempo (minutos) você gasta em cada uma das atividades seguintes; (3) registre o tempo em minutos; (4) preencha a planilha de Excel', Modelo Meu Inventário Pessoal do Tempo; e (5) traga a anotação para a próxima aula para ser postada on-line.

\subsection{Perfil dos respondentes}

No primeiro semestre de 2019, havia mais de 200 alunos matriculados no primeiro período do curso de Direito. Tiramos uma amostragem desta atividade de 133 estudantes, entre os quais 75 eram mulheres e 58 homens, de duas turmas da manhá, totalizando 84 , e duas turmas da noite, perfazendo um total de 49. A idade dos participantes variou entre 18 e 50 anos. Em resumo, a maioria não trabalhava, 89 (66,9\%). Quanto ao turno, 63,2\% estudavam no período da manhã. Existiam dez grupos etários: o maior grupo com $111(83,5 \%)$ alunos entre 18 e 19 anos e o segundo maior, entre 20 e 21 anos, tinha 10 (7,5\%). Quanto ao gênero, as 75 mulheres representavam 56,4\%. Além disso, a média geral de tempo gasto mexendo no celular é de 197 minutos; 136 minutos é a média para o estudo pessoal ( $9,4 \%$ do dia) e 107 minutos é a média para o trabalho (7,4\% do dia).

$17 \mathrm{O}$ experimento completo envolveu quatro momentos: instruçóes orais, instruçôes escritas, observação e registro e postagem. O primeiro momento consistiu nas instruçốes prévias em sala (oral). Foi explicado aos discentes o que eram as 14 atividades e como registrar o tempo. No segundo momento, os estudantes deveriam acessar às instruções escritas postadas na Comunidade da turma no Portal Acadêmico. No terceiro momento, os discentes realizariam a observação e o registro do tempo gasto com cada atividade. O quarto momento era o da postagem dos resultados durante a aula por meio de um link. As 14 atividades eram: sono, trabalho, aulas, conversa com familiares, deslocamento, mexendo no celular, refeiçóes, higiene pessoal, tarefas domésticas, atividade física, atividade espiritual, assistir à televisão e outras atividades. 


\subsection{Celular versus estudo pessoal no cotidiano dos estudantes}

Examinaremos somente o resultado referente ao uso do tempo mexendo no celular e o estudo pessoal de 62 estudantes que não trabalhavam. A atividade "Mexendo no celular" englobava tempo gasto jogando, recebendo e fazendo chamadas, recebendo e enviando mensagens (texto, imagem, áudio e vídeo), buscando informaçóes (produtos, mapas, serviços etc.), assistindo a vídeos, ouvindo música, comprando ou vendendo, baixando aplicativos, acessando redes sociais. Já o “Estudo pessoal” consistia no tempo dedicado à revisão de conteúdo das aulas, estudo de conteúdos relacionados (tarefas) a cada disciplina e leituras relacionadas (aprofundamento, pesquisa) às aulas. O estudo pessoal é uma atividade importante segundo o conceito de importância da Tríade. A segunda atividade mexendo no celular, em excesso, é uma atividade circunstancial.

\subsection{As categorias de uso de tempo em relaçáo ao tempo de estudo}

A Tabela 1 (a seguir) mostra, em números absolutos e relativos, o uso do tempo nas duas atividades pelos estudantes do período diurno. Constatam-se 14 categorias de usuários de tempo de celular: (1) menos de 1 hora ( 0 a 59 minutos); (2) 1 hora a $1 \mathrm{~h} 30 \mathrm{~min}$ (60 a 90 minutos); (3) mais de $1 \mathrm{~h} 31 \mathrm{~min}$ a 2 horas (91 a 120 minutos); (4) mais de $2 \mathrm{~h} 01 \mathrm{~min}$ a $2 \mathrm{~h} 30 \mathrm{~min}$ (121 a 150 minutos); (5) mais de $2 \mathrm{~h} 31 \mathrm{~min}$ a 3 horas (151 a 180 minutos); (6) mais de $3 \mathrm{~h} 01 \mathrm{~min}$ a $3 \mathrm{~h} 30 \mathrm{~min}$ (181 a 210 minutos); (7) mais de $3 \mathrm{~h} 31 \mathrm{~min}$ a 4 horas (211 a 240 minutos); (8) mais de $4 \mathrm{~h} 01 \mathrm{~min}$ a $4 \mathrm{~h} 30 \mathrm{~min}$ (241 a 270 minutos); (9) mais de $4 \mathrm{~h} 31 \mathrm{~min}$ a 5 horas (271 a 300 minutos); (10) mais de $5 \mathrm{~h} 01 \mathrm{~min}$ a $5 \mathrm{~h} 30 \mathrm{~min}$ (301 a 330 minutos); (11) mais de $5 \mathrm{~h} 31 \mathrm{~min}$ a 6 horas (331 a 360 minutos); (12) mais de $6 \mathrm{~h} 01 \mathrm{~min}$ a $6 \mathrm{~h} 30 \mathrm{~min}$ (361 a 390 minutos); (13) mais de $6 \mathrm{~h} 31 \mathrm{~min}$ a 7 horas (391 a 420 minutos); e (14) mais de $9 \mathrm{~h} 31 \mathrm{~min}$ a 10 horas (571 a 600 minutos). Ela mostra que a média de tempo gasto com o celular é maior, 216 minutos (15\% do dia), do que o tempo dedicado ao estudo pessoal, 151 minutos (10,5\% do dia). Também que a categoria 7 de usuários de tempo de celular abarca 13 (21\%) estudantes, gastando 237,3 minutos (16,48\% do dia) com o celular. Porém, apenas 2 (3,2\% dos alunos desse período) dedicam mais tempo do seu dia ao estudo pessoal, cerca de 165 minutos $(11,46 \%)$, e gastam menos de 1 hora com o celular. 
Tabela 1 Total de estudantes que trabalham segundo turno, média diária absoluta e relativa de minutos por atividade $-2019 / 1$

\begin{tabular}{|c|c|c|c|c|c|c|}
\hline \multirow{4}{*}{$\begin{array}{l}\text { Quantidade de minutos } \\
\text { por atividade }\end{array}$} & \multicolumn{6}{|c|}{ Total de estudantes da manhã que náo trabalham } \\
\hline & \multicolumn{6}{|c|}{$\begin{array}{l}\text { Média diária de minutos por atividade em dia de } 1.440 \text { minutos (24 } \\
\text { horas) }\end{array}$} \\
\hline & \multicolumn{3}{|c|}{ Absoluta } & \multicolumn{3}{|c|}{ Relativa (\%) } \\
\hline & Total & $\begin{array}{l}\text { Mexendo } \\
\text { no celular }\end{array}$ & $\begin{array}{l}\text { Estudo } \\
\text { pessoal }\end{array}$ & Total & $\begin{array}{l}\text { Mexendo } \\
\text { no celular }\end{array}$ & $\begin{array}{l}\text { Estudo } \\
\text { pessoal }\end{array}$ \\
\hline Total Geral & 62 & 216,0 & 151,0 & $100 \%$ & 15,0 & 10,5 \\
\hline \multicolumn{7}{|l|}{ Minutos por atividade } \\
\hline 0 a 59 minutos & 2 & 47,5 & 165,0 & 3,2 & 3,30 & 11,46 \\
\hline 60 a 90 minutos & 8 & 73,1 & 174,4 & 12,9 & 5,08 & 12,11 \\
\hline 91 a 120 minutos & 4 & 115,0 & 241,3 & 6,5 & 7,99 & 16,75 \\
\hline 121 a 150 minutos & 1 & 135,0 & 270,0 & 1,6 & 9,38 & 18,75 \\
\hline 151 a 180 minutos & 9 & 177,2 & 143,9 & 14,5 & 12,31 & 9,99 \\
\hline 181 a 210 minutos & 6 & 194,0 & 152,3 & 9,7 & 13,47 & 10,58 \\
\hline 211 a 240 minutos & 13 & 237,3 & 135,0 & 21 & 16,48 & 9,38 \\
\hline 241 a 270 minutos & 2 & 262,0 & 120,0 & 3,2 & 18,19 & 8,33 \\
\hline 271 a 300 minutos & 10 & 296,5 & 159,0 & 16,1 & 20,59 & 11,04 \\
\hline 301 a 330 minutos & 1 & 320,0 & 50,0 & 1,6 & 22,22 & 3,47 \\
\hline 331 a 360 minutos & 1 & 360,0 & 180,0 & 1,6 & 25,00 & 12,50 \\
\hline 361 a 390 minutos & 1 & 375,0 & 120,0 & 1,6 & 26,04 & 8,33 \\
\hline 391 a 420 minutos & 3 & 400,0 & 70,0 & 4,8 & 27,78 & 4,86 \\
\hline 571 a 600 minutos & 1 & 547,0 & 30,0 & 1,6 & 37,99 & 2,08 \\
\hline
\end{tabular}

Fonte: Relatório NEP - Inventário Pessoal do Tempo - 2019/1.

A Tabela 1 trouxe o uso do tempo dos estudantes do período matutino. Uma vez que estudo pessoal é uma atividade importante para a formação profissional, acadêmica e cidadá, o tempo dedicado a ela deveria ser muito superior ao de uso do celular. Mas a realidade mostrada na Tabela 2 é o inverso. Em média, os discentes gastam mais de 3 horas diárias (219,2 minutos) mexendo no celular, que é uma atividade circunstancial - e o recomendável seria gastar até 144 minutos (2,4 horas). Pode-se concluir que as categorias 5 a 7 (151 a 240 minutos) de uso de tempo com o celular concentram $28(45,1 \%)$ estudantes nesta categoria de atividade. Esse grupo consome de 3 a 4 horas com o celular. Sua característica comum é que gastam mais tempo com o celular do que com o estudo pessoal. Essa 
característica vai se repetir com o restante dos grupos (8 a 14) com o agravante de que quanto mais aumenta o tempo de celular, mais diminui o tempo de estudo pessoal. Nota-se que existem 15 alunos (24,2\%) nos grupos de 1 a 4 (0 a 150 minutos) que estão dentro do ideal com essa atividade. A característica comum entre eles é o maior tempo dedicado ao estudo pessoal (atividade importante) e o menor tempo com o celular.

\subsection{Invertendo as categorias de uso de celular e tempo estudo pessoal}

Tabela 2 Total de estudantes que trabalham segundo turno, média diária absoluta e relativa de minutos por atividade $-2019 / 1$

\begin{tabular}{|c|c|c|c|c|c|c|}
\hline \multirow{4}{*}{$\begin{array}{l}\text { Quantidade de minutos por } \\
\text { atividade }\end{array}$} & \multicolumn{6}{|c|}{ Total de estudantes da manhá que náo trabalham } \\
\hline & \multicolumn{6}{|c|}{$\begin{array}{l}\text { Média diária de minutos por atividade em dia de } 1440 \text { minutos } \\
\text { (24horas) }\end{array}$} \\
\hline & \multicolumn{3}{|c|}{ Absoluta } & \multicolumn{3}{|c|}{ Relativa (\%) } \\
\hline & Total & $\begin{array}{l}\text { Mexendo } \\
\text { no Celular }\end{array}$ & $\begin{array}{l}\text { Estudo } \\
\text { Pessoal }\end{array}$ & Total & $\begin{array}{c}\text { Mexendo } \\
\text { no } \\
\text { Celular } \\
\end{array}$ & $\begin{array}{l}\text { Estudo } \\
\text { Pessoal }\end{array}$ \\
\hline Total Geral & 62 & 216 & 151 & $100 \%$ & 15 & 10,5 \\
\hline \multicolumn{7}{|l|}{ Minutos por atividade } \\
\hline 571 a 600 minutos & 1 & 547 & 30 & 1,6 & 37,99 & 2,08 \\
\hline 301 a 330 minutos & 1 & 320 & 50 & 1,6 & 22,22 & 3,47 \\
\hline 391 a 420 minutos & 3 & 400 & 70 & 4,8 & 27,78 & 4,86 \\
\hline 241 a 270 minutos & 2 & 262 & 120 & 3,2 & 18,19 & 8,33 \\
\hline 361 a 390 minutos & 1 & 375 & 120 & 1,6 & 26,04 & 8,33 \\
\hline 211 a 240 minutos & 13 & 237,3 & 135 & 21 & 16,48 & 9,38 \\
\hline 151 a 180 minutos & 9 & 177,2 & 143,9 & 14,5 & 12,31 & 9,99 \\
\hline 181 a 210 minutos & 6 & 194 & 152,3 & 9,7 & 13,47 & 10,58 \\
\hline 271 a 300 minutos & 10 & 296,5 & 159 & 16,1 & 20,59 & 11,04 \\
\hline 0 a 59 minutos & 2 & 47,5 & 165 & 3,2 & 3,3 & 11,46 \\
\hline 60 a 90 minutos & 8 & 73,1 & 174,4 & 12,9 & 5,08 & 12,11 \\
\hline 331 a 360 minutos & 1 & 360 & 180 & 1,6 & 25 & 12,5 \\
\hline 91 a 120 minutos & 4 & 115 & 241,3 & 6,5 & 7,99 & 16,75 \\
\hline 121 a 150 minutos & 1 & 135 & 270 & 1,6 & 9,38 & 18,75 \\
\hline
\end{tabular}

Fonte: Relatório NEP - Inventário Pessoal do Tempo - 2019/1. 
A Tabela 2 é uma inversão da anterior porque foi agrupada a partir da média de tempo de estudo pessoal. Seguindo um método similar ao agrupamento do tempo mexendo no celular, temos 5 categorias de tempo de estudo pessoal: (1) Menos de 1 hora (30 a 50 minutos); (2) de 1 hora a 2 horas (70 a 120 minutos); (3) mais de 2 horas até $2 \mathrm{~h} 30 \mathrm{~min}$ ( 135 a 143,9 minutos); (4) de $2 \mathrm{~h} 30 \mathrm{~min}$ a 3 horas (152,3 a 180 minutos); e (5) mais de 4 horas a 4 h30min (241,3 a 270 minuto). A categoria 1 (menos de 1 hora) apresenta 2 estudantes e representa $3,2 \%$ do total. Sua característica comum é consumir de 6 a 18 vezes mais tempo com o celular do que com o estudo pessoal. A categoria 2 (de 1 hora a 2 horas) é composta por 6 alunos e representa $9,6 \%$. Eles têm em comum o fato de gastaram de 3 a 5 vezes mais tempo com o celular do que com o estudo. A categoria 3 (mais de 2 horas até $2 \mathrm{~h} 30 \mathrm{~min}$ ) é composta por 22 alunos e representa $35,5 \%$. Sua característica comum é gastar menos de 2 vezes mais tempo com o celular do que com o estudo. A categoria 4 (de $2 \mathrm{~h} 30 \mathrm{~min}$ a 3 horas) é composta por 27 alunos e representa 43,5\%. É a mais heterogênea porque é constituída por 17 (27,4\%) alunos que gastam até 2 vezes mais tempo com o celular do que com o estudo pessoal. E a outra parte, ainda que coincida em quantidade de horas dedicadas ao estudo pessoal ( $2 \mathrm{~h} 30 \mathrm{~min}$ a 3 horas), é formada por um grupo de 10 alunos completamente oposto. Eles gastam mais tempo com o estudo pessoal do que com o celular. Esses estudantes representam 16,1\%. Sua característica comum é: gastaram de 2 a 3 vezes mais tempo com o estudo pessoal do que com o celular. A categoria 5 (mais de 4 horas a $4 \mathrm{~h} 30 \mathrm{~min}$ ) é composta por 5 alunos e representa $8,1 \%$. Sua característica comum é: gastaram até 2 vezes mais tempo com o estudo pessoal do que com o celular. De fato, conforme o critério de mais tempo de estudo no que concerne ao celular, os $10(16,1 \%)$ estudantes da categoria 4 seriam os maiores representantes da categoria 5 .

\section{$5 \mathrm{O}$ que sugerem os resultados de gasto com celular e com o estudo pessoal? Que consequências tem o uso excessivo do celular para a formação jurídica?}

Aplicando a Tríade na prática diária, o uso ideal do tempo seria dedicar 70\% dele, aproximadamente 16,8 horas (1.008 minutos), às atividades importantes. As atividades urgentes deveriam consumir, em média, $20 \%$ do tempo, isso equivale a aproximadamente 4,8 horas (288 minutos). Essas atividades eram importantes, mas foram negligenciadas e agora demandam ação imediata, acarretando a interrupção das atividades importantes em curso, por isso elas geram estresse e tensão. Por fim, as atividades circunstanciais são aquelas que não contribuem 
nem aproximam a pessoa de seus objetivos. As interferências e interferência de objetivo, causadas pelo celular, se enquadram nessa categoria. Hipoteticamente, apenas 2,4 horas ( $10 \%$ do tempo) - 144 minutos, em média - deveriam ser gastas diariamente com atividades desse tipo. Além de gastar seu tempo com uma atividade que não os aproxima de seus objetivos, que outras consequências recairão sobre os estudantes? É possível inferir consequências de curto e longo prazo para esse hábito dos estudantes.

\subsection{Consequências em currto prazo}

Em curto prazo, o estudante que gasta mais tempo com o celular tem menos tempo de estudo pessoal diário. As cinco categorias de tempo de estudo pessoal da Tabela 2 eram: (1) menos de 1 hora; (2) de 1 hora a 2 horas; (3) mais de 2 horas até $2 \mathrm{~h} 30 \mathrm{~min}$; (4) de $2 \mathrm{~h} 30 \mathrm{~min}$ a 3 horas; e (5) mais de 4 horas a $4 \mathrm{~h} 30 \mathrm{~min}$. De acordo com tais categorias, é possível fazer uma projeção de média de tempo de estudo semanal (Tabela 3 a seguir) dos discentes. Os estudantes da categoria 1 (Menos de 1 hora - 30 a 50 minutos) poderão estudar de 3 a 6 horas. Aqueles pertencentes à categoria 2 (de 1 hora a 2 horas - 70 a 120 minutos - poderáo ter de 8 a 14 horas de estudo. Os discentes da categoria 3 (mais de 2 horas até $2 \mathrm{~h} 30 \mathrm{~min}-135$ a 143,9 minutos - poderão estudar de 15 a 17 horas. Os estudantes da categoria 4 (de $2 \mathrm{~h} 30$ min a 3 horas - 152,3 a 180 minutos) terão a possibilidade de estudar de 18 a 21 horas. Por fim, os estudantes da categoria 5 (mais de 4 horas a 4h30min - 241,3 a 270 minutos) poderão estudar de 28 a 31 horas. O aprendizado é um ato pessoal que se efetiva em sua maioria fora da sala de aula. A aprendizagem profunda (significativa) acontece no tempo dedicado às leituras preparatórias para a aula, à revisão de conteúdo das aulas em casa, ao estudo de conteúdos relacionados (tarefas) a cada disciplina e às leituras relacionadas (aprofundamento, pesquisa) às aulas. Portanto, quanto menor o tempo de estudo pessoal, menor a possibilidade de aprendizado.

Tabela 3 Média de tempo de estudo

\begin{tabular}{|c|c|c|}
\hline $\begin{array}{c}\text { Média de tempo de estudo } \\
\text { por 1 dia (min.) }\end{array}$ & $\begin{array}{c}\text { Média de tempo de estudo em } \mathbf{1} \\
\text { semana - 7 dias - (min.) }\end{array}$ & $\begin{array}{c}\text { Média de horas de estudo } \\
\text { pessoal por semana }\end{array}$ \\
\hline 30 & 210 & 3,5 \\
\hline 50 & 350 & 5,8 \\
\hline 70 & 490 & 8,2 \\
\hline 120 & 840 & 14,0 \\
\hline
\end{tabular}




\begin{tabular}{|c|c|c|}
\hline 120 & 840 & 14,0 \\
\hline 135 & 945 & 15,8 \\
\hline 143,9 & 1007,3 & 16,8 \\
\hline 152,3 & 1066,1 & 17,8 \\
\hline 159 & 1113 & 18,6 \\
\hline 165 & 1155 & 19,3 \\
\hline 174,4 & 1220,8 & 20,3 \\
\hline 180 & 1260 & 21,0 \\
\hline 241,3 & 1689,1 & 28,2 \\
\hline 270 & 1890 & 31,5 \\
\hline
\end{tabular}

Fonte: Elaborado pelos autores - 2019/1.

A outra consequência desastrosa é o baixo desempenho acadêmico. O curso de Direito é bastante desafiador para os estudantes calouros porque a terminologia jurídica não é familiar à população. Para superar esse gap semântico, a leitura de textos jurídicos e de dicionário jurídico é o método mais eficiente para a formação do vocabulário do estudante. Sem um vocabulário jurídico adequado, o discente terá uma interpretação e compreensão bastante empobrecidas. Outra dificuldade que afeta a população estudantil, mesmo fora do Direito, é a leitura de textos curtos (curtíssimos no caso de postagens das redes sociais) on-line. O estudante descobre que o curso de Direito é bastante exigente, pois a linguagem é difícil e os textos jurídicos são longos e herméticos. Conforme Gonçalves et al. (2015), o tempo de estudo pessoal influenciou 36\% do rendimento acadêmico dos alunos do $1^{\circ}$ período do Direito. Por essa razáo, o tempo de estudo insuficiente (pouco) vai empurrar o aluno para o desempenho inferior ao que ele poderia ter.

A próxima consequência negativa são as reprovaçóes. Um discente que estuda pouco, porque gasta mais tempo mexendo no celular, não se prepara adequadamente para as avaliaçôes da aprendizagem. Geralmente, o aluno que consome tempo demais com o celular tem dificuldade de desligá-lo durante o tempo de estudo. Aliás, McCoy (2015) comprovou que eles têm dificuldade de fazer isso até mesmo durante as aulas. Assim, o aluno que tenta estudar com o celular ligado sofre distraçôes (informaçôes irrelevantes) ou interrupçôes (multitarefas) contínuas, as quais são prejudiciais durante o estudo pessoal porque interrompem a atenção, o foco do do estudo que está realizando (GAZZALEY; ROSEN, 2016). As recuperaçóes e as reprovaçôes são resultado previsível do aprendizado insuficiente ou do não aprendizado. 


\subsection{Consequências em longo prazo}

Em longo prazo, o uso diário desmedido do celular, conforme constatado anteriormente, provocará outras consequências negativas à formação do futuro operador do Direito e também à sociedade. Pois, o Direito é uma ciência social aplicada e, como tal, aplica as teorias sociais para resolver os problemas da sociedade (DEMO, 1985). Mais especificamente, o Direito ${ }^{18}$ tem uma função social reguladora de conflitos e pacificadora da sociedade. Por isso, a formação superficial, provavelmente, de um operador do Direito é mais danosa consequência para a sociedade.

O acirramento das desigualdades é outra consequência deletéria para a sociedade. Como os operadores do Direito devem pacificar e resolver os conflitos sociais - frutos de interesses divergentes ou de desigualdades inerentes ao sistema social -, o desempenho competente de suas funções pode contribuir para mitigação das desigualdades sociais. Entretanto, a formação superficial, por negligência ou outro motivo, durante o tempo de estudante universitário solapará o desempenho competente da atividade jurídica, contribuindo para o acirramento das desigualdades.

Além disso, o graduado com formação superficial terá maior vulnerabilidade na inserção no mercado de trabalho cada vez mais exigente. Sales e Bezerra (2018) estão indicando que a ausência de novas competências e habilidades adequadas ao mundo tecnológico afetará a empregabilidade. Para Harari (2018), as habilidades mais necessárias neste mundo em mudança serão saber lidar com as mudanças, aprender novos assuntos e preservar o equilíbrio mental. Em direçáo semelhante aponta o Fórum Econômico Mundial por meio dos seus Relatórios The Future of Jobs Report, 2016 e 2018. Além de fazer uma análise de como a 4a Revolução Industrial afetará os diferentes setores da economia dos países e a necessidade de requalificação profissional, ele indica um pacote de competências que serão necessárias ao mundo em mudança. O Relatório de 2018 colocou aprendizado ativo e estratégias de aprendizagem ${ }^{19}$ no topo das competências. $\mathrm{O}$ segundo pacote é composto por leitura, escrita, matemática e escuta ativa ${ }^{20}$. Logo, pode-se concluir que a negligência do acadêmico durante a formação universitária deixará o futuro profissional com menores chances em um mercado profissional mais competitivo e em mudanças constantes.

18 Há várias concepçôes de Direito. A de Dimoulis (2016, p. 18-19) é pertinente ao nosso propósito: “Direito é o conjunto de normas que objetivam regulamentar o comportamento das pessoas na sociedade. Essas normas săo editadas pelas autoridades competentes e preveem, em caso de violação, a imposição de penalidades por órgãos do Estado."

19 No original "Active learning and learning strategies".

20 No original "Reading, writing, math, active listening". 
Por fim, o uso excessivo do celular pode criar nos jovens maior suscetibilidade a problemas relacionados à saúde psíquica, de socialização, doenças musculoesqueléticas e outros riscos ${ }^{21}$. A TIC Kids de 2015 refletiu com precisão sobre os desafios para a saúde das crianças e dos adolescentes em decorrência do uso crescente e precoce das TICs. Os autores dividiram os desafios de acordo com os seguintes aspectos: (1) crescimento e desenvolvimento corporal; (2) saúde mental e comportamental; (3) sexualidade e desenvolvimento sexual; e (4) riscos à saúde em geral. Com referência ao item 4, foram listados os riscos visuais, riscos auditivos, riscos posturais e osteoarticulares e riscos alimentares (NIC-BR, 2015). Há estudos associando o uso excessivo de celular ao narcisismo, a problemas de sono, isolamento, problemas de socialização, risco de suicídio e baixa tolerância às frustrações (TWENGE, 2018).

\subsection{Por que os jovens usam o celular e a internet mais para diversáo do que para o estudo?}

Embora o celular seja uma ferramenta e uma porta que permite o acesso ao conhecimento (estudo, pesquisa etc.) e à produtividade, por que a maioria dos jovens usam o celular e a internet para diversão e entretenimento? Talvez, porque desde crianças tenham aprendido a usá-los para isso. É o que demonstra a Pesquisa sobre o uso da Internet por crianças e adolescentes no Brasil: TIC Kids Online Brasil22.

A pesquisa de 2009 concentrou-se somente na população de 5 a 9 anos. Ela mostrou que o celular era a tecnologia mais difundida entre o público pesquisado, pois $64 \%$ já tinham usado o aparelho e $14 \%$ possuíam um. Quanto ao acesso à internet, 29\% declararam já ter acessado. As atividades na internet eram predominantemente lúdicas com destaque para os jogos (97\%) e atividades de comunicação e educação $(46 \%)$ eram pouco realizadas. A conclusão era de que o uso do celular era para a diversão (88\%) (NIC-BR, 2010).

A TIC crianças 2010 demonstra que as redes sociais (Facebook e Orkut) já faziam parte da vida de $29 \%$ das crianças de 5 a 9 anos. As atividades na internet

21 No artigo Pessoas que só usam internet para xingar outras pessoas": incômodos de crianças e adolescentes brasileiros na internet, as autoras trazem uma família de 6 códigos para classificar os riscos enfrentados pelas crianças e pelos adolescentes na internet. São eles: “1) Risco de conteúdo - composto por códigos que descrevem conteúdos impactantes para os participantes; 2) Risco de conduta - composto por códigos que configuram desrespeito ou inadequaçăo; 3) Percepçāo de sexo - percepçáo de conteúdo sexual (por exemplo, mulher nua, nudez); 4) Risco tecnológico - códigos que indicam incômodo com uso inadequado da tecnologia; 5) Risco de contato - queixas de pessoas desconhecidas que insistem em fazer contato ou que assediam; 6) Percepçáo de conteúdo violento - cenas, textos ou vídeos com violência" (NIC-BR, 2015, p. 106).

22 Essa é uma pesquisa anual e de abrangência nacional, realizada pelo Núcleo da Informação e Coordenação do Ponto BR - NIC-BR desde 2009. Seu objetivo é compreender de que forma a população de 9 a 17 anos de idade utiliza a Internet e como lida com os riscos e as oportunidades decorrentes desse uso. Na primeira e segunda ediçóes, $2009 \mathrm{e}$ 2010, seu nome era Pesquisa sobre o uso das Tecnologias da Informação e da Comunicação no Brasil- TIC Crianças. Para obter mais informaçôes sobre a história do NIC-BR consulte o link: https://nic.br/historia/. Acesso em: 4 nov. 2019. 
eram predominantemente lúdicas com destaque para os jogos (90\%), depois procurar material para escola (45\%) e brincar em sites que têm desenho (42\%). O celular era usado por $84 \%$ das crianças para jogar (NIC-BR, 2011).

A partir de 2012, o nome da pesquisa foi mudado para Pesquisa sobre o uso da Internet por crianças e adolescentes no Brasil: TIC Kids Online Brasil. A pesquisa modificou a faixa etária de amostragem de 5 a 9 anos para 9 a 16 anos. Ela revelou uma nova perspectiva sobre $\mathrm{o}$ acesso dos jovens ao celular e à internet. $\mathrm{O}$ acesso à internet via celular atingiu $21 \%$ da população pesquisada. As atividades realizadas na rede diariamente "todos os dias" e "quase todos os dias" continuavam mais ligadas à comunicação e ao entretenimento ${ }^{23}$.

Para atividades escolares, somente $13 \%$. A pesquisa perguntava também pela frequência mensal às mesmas atividades. Surpreendentemente, $82 \%$ das crianças e adolescentes declaravam que utilizavam a internet para "trabalhos escolares" (NIC-BR, 2013). No entanto, a análise demonstra que na prática cotidiana somente $13 \%$ utilizavam a internet para fins educativos.

Há um breve resumo de 2013 e 2014 na nota de rodapé $21^{24}$. Em 2015, o acesso à internet via celular, entre a faixa etária de 9 a 17 anos era $84 \%$, chegou a $91 \%$ (2016), a 93\% (2017) e se manteve com esse percentual em 2018 (NICBR, 2015, 2016, 2017 e 2018). Mas, como estavam gastando o tempo nas atividades na internet? Vamos fazer uma análise de crescimento da frequência de 2015 a 2018 das seguintes atividades: (1) "Mensagens instantâneas"; (2) "Jogou on-line, conectado com outros jogadores"; (3) "Joga on-line, não conectado com outros jogadores"; (4) "Pesquisou na internet para fazer trabalhos escolares"; (5) "Pesquisou na internet por curiosidade ou por vontade própria"; (6) "Usou redes sociais"; (7) "Assistiu a vídeos, programas, filmes ou séries na internet”; e (8) "Ouviu música na Internet". Usaremos dois critérios ("Mais de uma vez por dia" e "Pelo menos uma vez por dia") desenvolvidos pelo NIC-BR. Os valores estão apresentados em percentual na Tabela 4 .

23 As atividades ligadas à comunicação e ao entretenimento são também mencionadas com destaque pelos jovens usuários de internet: assistir a vídeos no YouTube (66\%), jogar com outras pessoas on-line (54\%) e trocar mensagens instantâneas na internet (54\%) estão entre as atividades mais citadas. Além disso, $44 \%$ das crianças e adolescentes afirmaram ter baixado músicas ou filmes e $42 \%$ lido ou assistido notícias pela internet. As postagens de fotos, vídeos ou músicas (40\%) são mais comuns do que a inserção de mensagens em sites (24\%), bem como do ato de escrever em um blog ou diário on-line (10\%) (NIC-BR, 2013, p. 136).

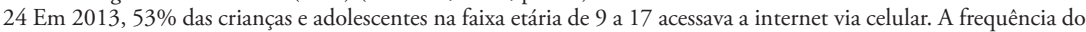
acesso se intensificou. O acesso "todos os dias ou quase todos os dias" chegou a $74 \%$ na população de 15 a 17 anos. As atividades mais frequentes eram ligadas à comunicaçáo e às redes sociais: mensagens instantâneas $(74 \%)$, rede social (63\%), YouTube (40\%), ler/assistir a notícias (36\%), e-mails (34\%), baixar músicas ou filmes (21\%). Para atividades escolares, somente $19 \%$ usavam diariamente. (NIC-BR, 2014). Em 2014, saltou de 53\% para 82\% o acesso à internet via celular na faixa etária de 9 a 17. De 15 a 17 anos, o percentual foi de $94 \%$. Ou seja, ultrapassou o computador que caiu de $71 \%$ para $51 \%$. A frequência do acesso se intensificou mais. $\mathrm{O}$ acesso "todos os dias ou quase todos os dias" chegou a $81 \%$ na população de 9 a 17 anos. As atividades mais frequentes eram comunicação e entretenimento na populaçáo de 11 a 17 anos. Com a frequência de "mais de uma vez por dia": mensagens instantâneas $(75 \%)$, rede social (56\%), ouvir música (44\%), YouTube (19\%), pesquisar coisas (23\%). Para trabalho escolar, somente $22 \%$. (NIC-BR, 2015). 
Essa mesma tabela demonstra que, na prática diária (2015-2018), o item "trabalhos escolares" teve o pior resultado nos quatro anos para o acesso "Mais de uma vez por dia”. O resultado de "Pelo menos uma vez por dia” não é o pior, porém, seu desempenho náo muito melhor. Ou seja, a pesquisa evidencia que os jovens de 9 a 17 anos usam a internet no celular para fazer vários outros objetivos diferentes dos educativos. Constata-se também o principal envio de mensagens (mais de $50 \%$ ) é o principal uso e o segundo maior é o uso de redes sociais (mais de $40 \%$ ).

Tabela 4 Total de usuários de internet de 9 a 17 anos, segundo indicador de uso de internet por crianças e adolescentes, percentual e anos - 2015 a 2018

\begin{tabular}{|c|c|c|c|c|}
\hline \multirow{4}{*}{ Frequência diária e tipo de atividades realizadas } & \multicolumn{4}{|c|}{$\begin{array}{c}\text { Indicador B2 - uso da internet para } \\
\text { atividades realizadas }\end{array}$} \\
\hline & \multicolumn{4}{|c|}{ Percentual } \\
\hline & \multicolumn{4}{|c|}{ Anos } \\
\hline & $2015^{1}$ & $2016^{2}$ & $2017^{3}$ & $2018^{4}$ \\
\hline \multicolumn{5}{|c|}{ Mais de uma vez por dia } \\
\hline Enviar mensagens instantâneas & 51,91 & 53,45 & 56,71 & 57,70 \\
\hline Jogou on-line, conectado com outros jogadores & 13,12 & 13,30 & 16,93 & 27,96 \\
\hline Joga on-line, não conectado com outros jogadores & 10,71 & 13,12 & 19,04 & 26,79 \\
\hline Pesquisou na internet para fazer trabalhos escolares & 13,10 & 13,15 & 18,38 & 17,03 \\
\hline $\begin{array}{l}\text { Pesquisou na internet por curiosidade ou por vontade } \\
\text { própria }\end{array}$ & 17,74 & 23,66 & 19,84 & 20,05 \\
\hline Usou redes sociais & 45,30 & 49,06 & 46,61 & 44,73 \\
\hline $\begin{array}{l}\text { Assistiu a vídeos, programas, filmes ou séries na } \\
\text { internet }\end{array}$ & 23,21 & 26,90 & 37,32 & 42,52 \\
\hline Ouviu música na internet & 27,83 & 30,23 & 43,21 & 48,71 \\
\hline \multicolumn{5}{|c|}{ Pelo menos uma vez por dia } \\
\hline Enviar mensagens instantâneas & 14,05 & 13,98 & 14,86 & 11,52 \\
\hline Jogou on-line, conectado com outros jogadores & 8,99 & 9,93 & 10,39 & 12,92 \\
\hline Joga on-line, não conectado com outros jogadores & 11,22 & 12,04 & 16,94 & 14,80 \\
\hline Pesquisou na internet para fazer trabalhos escolares & 16,21 & 16,27 & 17,66 & 16,47 \\
\hline $\begin{array}{l}\text { Pesquisou na internet por curiosidade ou por vontade } \\
\text { própria }\end{array}$ & 18,31 & 18,64 & 18,73 & 19,10 \\
\hline Usou redes sociais & 16,52 & 15,37 & 16,56 & 12,59 \\
\hline $\begin{array}{l}\text { Assistiu a vídeos, programas, filmes ou séries na } \\
\text { internet }\end{array}$ & 15,03 & 15,70 & 20,73 & 20,47 \\
\hline Ouviu música na internet & 13,63 & 15,32 & 17,62 & 20,51 \\
\hline
\end{tabular}

Fonte: Elaborado pelos autores - 2019/ 1. 
Essa tabela demonstra, ainda, que houve crescimento (evolução) das atividades nos últimos 4 anos, com exceção do "uso de redes sociais" que teve decréscimo entre - $0,6 \%$ e -3,9\%, bem como "enviar mensagens instantâneas" que teve decréscimo de $-2,5 \%$ para o acesso de "Pelo menos uma vez por dia". Ela evidencia que, na prática diária, o item "trabalhos escolares" teve um crescimento de 3,9 para o acesso "Mais de uma vez por dia" e 0,3\% para "Pelo menos uma vez por dia”. Entretanto, em comparaçáo com as demais atividades, os resultados confirmam a inexpressividade do uso da internet via celular para fins educativos entre os jovens de 9 a 17 anos. Isto é, o uso que fazem é majoritariamente voltado para ouvir música $(20,9)$, assistir a vídeos ou séries $(19,3)$, jogar on-line, não conectado com outros jogadores $(16,1)$ e jogar on-line, conectado com outros jogadores $(14,8)$.

\section{$5.4 \mathrm{O}$ que fazer?}

O que as instituiçôes educacionais, educadores e pessoas responsáveis pela formação dos estudantes podem fazer diante desse cenário? O desafio é grande porque se trata de hábitos culturais tecnológicos arraigados na vida dos nativos da era digital. Instituiçôes, educadores, pais ou responsáveis e agentes públicos precisam trabalhar na elaboração de políticas nas esferas públicas e privadas para o desenvolvimento de competências e habilidades digitais. As instituiçôes educativas devem elaborar políticas para o desenvolvimento da competência digital, que envolvam toda a comunidade acadêmica - professores, alunos, corpo técnicoadministrativo e sociedade civil (pais e responsáveis). Criar espaços de análise de dados sobre a utilização excessiva de recursos tecnológicos, sobretudo aparelhos celulares, e de reflexão para contribuir para a busca de equilíbrio e desenvolver habilidades e competências de gestão do tempo em função da formação acadêmica. Não bastam açóes de capacitação somente de um segmento. Cabem em todos os âmbitos da administração pública a elaboração e o desenvolvimento de políticas públicas de alfabetização midiática e digital da população em geral, sobretudo, no que concerne ao campo da educação.

Por fim, parece-nos útil assimilar duas grandes orientaçôes de Aristóteles $(2009)^{25}$ : a primeira é de que para sermos pessoas capazes de exercer influência e fazer a diferença, é necessário sermos bons naquilo que fazemos, capazes de

25 “[...] quem propóe como tarefa alterar para uma boa disposição quem quer que seja não poderá ser uma pessoa qualquer, mas, se, de todo, houver alguém que o consiga, terá de ser o perito nessa área, tal como acontece com a medicina e as restantes áreas onde operam uma certa preocupaçáo e sensatez." [...] "Os que são experientes a respeito de cada pormenor em particular discernem corretamente os produtos [de uma determinada produçáo] e têm consciência dos meios e do modo como podem vir a ser realizados e quais as partes que concordam entre si" (ARISTÓTELES, 2009, p. 243-245). 
agir de maneira refletida, equilibrada, produtiva e com perícia, portanto, com excelência. A segunda está estreitamente ligada à primeira, alertando para o fato de que aqueles(as) que têm experiência e conhecimento de como as coisas são, ou de como devem ser, têm consciência dos meios e modos como as coisas devem ser realizadas, ou seja, são pessoas capazes de ter clareza dos fins e discernir sobre a aplicação correta de como atingir os fins pretendidos. Para nossa reflexão, os fins são a aprendizagem, o desenvolvimento pessoal, o desempenho e o aproveitamento acadêmicos, bem como a excelência acadêmica e ética. Os meios são os mais diversos recursos como smartphones, internet, redes sociais etc. É preciso ficarmos muito atentos a fim de desenvolvermos as habilidades e competências necessárias para gerirmos bem nossa vida e nosso tempo na busca da realização pessoal, acadêmica e profissional.

\section{Consideraçóes finais}

A análise comprovou que o uso excessivo do celular entre estudantes que náo trabalham diminuiu o tempo de dedicaçáo ao estudo pessoal. A Tabela 1 evidenciou que $75 \%$ dos estudantes do experimento gastam mais tempo mexendo no celular do que com o estudo pessoal. Ou seja, apenas $25 \%$ dos discentes gastam mais tempo com o estudo pessoal do que com o celular. Os estudantes que afirmavam dedicar mais tempo ao estudo pessoal dispendiam até $2 \mathrm{~h} 30 \mathrm{~min}$ com o celular em oposiçấo ao outro grupo.

Os dados demonstram que o uso excessivo do celular gera várias consequências para a formaçãa do futuro jurista, sendo a diminuição do tempo dedicado ao estudo (atividade importante) a primeira delas. Além disso, o celular se torna uma interferência na forma de distraçóes (informaçóes irrelevantes) ou interrupçóes externas. As interferências excessivas e contínuas solapam a concentração, a atenção e o interesse que são estados mentais essenciais ao aprendizado e à formação do estudante e futuro profissional.

O uso ideal do tempo deve ser de $70 \%$ aplicado às atividades importantes que envolvam tempo para si mesmo e pessoas próximas, planejamento, organizaçáo, execução, realização pessoal, definição de objetivo, metas, prazos, monitoramento de resultado e saúde física e mental (sono, higiene, esporte, lazer, alimentação), tendo em vista que são tais atividades que geram algum resultado, aproximam ou contribuem de alguma maneira para a concretização dos objetivos do estudante. Estudar diariamente possibilita ao estudante de Direito adquirir uma sólida formação jurídica essencial para o exercício da cidadania e para a atuação profissional e como pesquisador, isto é, colabora para que o estudante realize as finalidades do ensino superior.

As evidências deste estudo confirmam que a maioria dos estudantes usa 
o celular para as quatro principais finalidades da população brasileira (IBGE, 2018a, 2018b), mais associadas às atividades circunstanciais, na linguagem da Tríade do Tempo, como entretenimento e comunicação do que às atividades importantes como estudo, pesquisa e outras atividades produtivas. Mostram, ainda, que o uso excessivo, portanto, desequilibrado, de aparelho celular, redes sociais, internet e outros recursos tecnológicos e midiáticos, tem exercido enorme distração, desviando a atenção dos(as) estudantes tanto em sala de aula como nos estudos extraclasse, levando a uma significativa perda de aprendizagem e, consequentemente, prejudicando o desempenho acadêmico.

\section{Referências}

ASSOCIAÇÃO BRASILEIRA DE NORMAS TÉCNICAS. NBR 6023: informação e documentação: referências: elaboração. Rio de Janeiro: ABNT, 2018. ARISTÓTELES. Ética a Nicômaco. São Paulo: Atlas, 2009.

BARBOSA, C. A tríade do tempo. Rio de Janeiro: Campus/Elsevier, 2008.

BOYD, J; ZIMBARDO, P. O paradoxo do tempo. Rio de Janeiro: Objetiva, 2009. BRASIL. Lei n. 9.394, de 20 de dezembro de 1996. Estabelece as diretrizes e bases da educação nacional. Brasília, DF: Presidência da República, [1996]. Disponível em: http://www.planalto.gov.br/ccivil_03/leis/19394.htm. Acesso em: 25 set. 2019.

BRASIL. Constituição Federal. Brasília: Presidência da República, 1988.

Disponível em: https://www.planalto.gov.br/ccivil_03/constituicao/constituicao. htm. Acesso em: 29 out. 2019.

BRASIL. Ministério da Educação. Conselho Nacional de Educação. Câmara de Educação Superior. Resolução n. 5, de 17 de dezembro de 2018. Institui as Diretrizes Curriculares Nacionais do Curso de Graduação em Direito e dá outras providências. Brasília: 2018. Disponível em: http://portal.mec.gov.br/ index.php?option=com_docman \&view=download \&alias=104111-rces00518\&category_slug=dezembro-2018-pdf\&Itemid=30192. Acesso em: 12 nov. 2019.

CARNEIRO, M. A. LDB fácil: leitura crítico-compreensiva, artigo a artigo. 23. ed. rev. e amp. Petrópolis: Vozes, 2015.

DEMO, P. Introdução ao ensino da metodologia da ciência. 2. ed. São Paulo: Atlas, 1985. 
DIMOULIS, D. Manual de introdução ao estudo do direito: definição e conceitos básicos, norma jurídica. 7. ed. rev. atual. e amp. São Paulo: Revista dos Tribunais, 2016.

GAZZALEY, A.; ROSEN, L. The distracted mind: ancient brains in a high-tech world. London: MIT Press, 2016.

GONÇALVES; M. P. G. et al. Influência do tempo de estudo no rendimento do aluno universitário. Revista Fundamentos, Teresina, v. 2, n. 2, 2015. Disponível em: http://www.ojs.ufpi.br/index.php/fundamentos/article/view/4745/2727. Acesso em: 14 ago. 2019.

HARARI, Y. N. 21 liçôes para o século XXI. São Paulo: Companhia das Letras, 2018.

INSTITUTO BRASILEIRO DE GEOGRAFIA E ESTATÍSTICA. Norma de apresentação tabular. Rio de Janeiro: IBGE, 1993. Disponível em: https:// biblioteca.ibge.gov.br/visualizacao/livros/liv23907.pdf. Acesso em: 10 out. 2017.

INSTITUTO BRASILEIRO DE GEOGRAFIA E ESTATÍSTICA. Acesso à internet e à televisáo e posse de telefone móvel celular para uso pessoal 2005. Rio de Janeiro: IBGE, 2007. Disponível em: https://biblioteca.ibge.gov.br/visualizacao/ livros/liv33982.pdf. Acesso em: 5 mar. 2019.

INSTITUTO BRASILEIRO DE GEOGRAFIA E ESTATÍSTICA. Acesso à internet e à televisáo e posse de telefone móvel celular para uso pessoal 2013. Rio de Janeiro: IBGE, 2015. Disponível em: https://biblioteca.ibge.gov.br/visualizacao/ livros/liv93373.pdf. Acesso em: 5 mar. 2019.

INSTITUTO BRASILEIRO DE GEOGRAFIA E ESTATÍSTICA. Acesso à internet e à televisáo e posse de telefone móvel celular para uso pessoal 2014. Rio de Janeiro: IBGE, 2016. Disponível em: https://biblioteca.ibge.gov.br/visualizacao/ livros/liv95753.pdf. Acesso em: 5 mar. 2019.

INSTITUTO BRASILEIRO DE GEOGRAFIA E ESTATÍSTICA. Acesso à internet e à televisáo e posse de telefone móvel celular para uso pessoal 2016. Rio de Janeiro: IBGE, 2018a. Disponível em: https://biblioteca.ibge.gov.br/visualizacao/ livros/liv101543.pdf. Acesso em: 5 mar. 2019.

INSTITUTO BRASILEIRO DE GEOGRAFIA E ESTATÍSTICA. Acesso à internet e à televisáo e posse de telefone móvel celular para uso pessoal 2017. Rio de Janeiro: IBGE, 2018b. Disponível em: https://biblioteca.ibge.gov.br/visualizacao/ livros/liv101631_informativo.pdf. Acesso em: 5 mar. 2019. 
INTERNATIONAL TELECOMMUNICATION UNION. Measuring the information society report 2018. Geneva: 2018. v. 1. Disponível em: https://www. itu.int/en/ITU-D/Statistics/Documents/publications/misr2018/MISR-2018Vol-1-E.pdf. Acesso em: 9 set. 2019.

KAPLAN, A. M.; HAENLEIN, M. Users of the world, unite! The challenges and opportunities of social media. Business Horizons, v. 53, n. 1, p. 59-68, 2010. Disponível em: https://www.researchgate.net/publication/222403703_Users_ of_the_World_Unite_The_Challenges_and_Opportunities_of_Social_Media. Acesso em: 15 ago. 2019.

LEPP, A.; BARKLEY, J. E.; KARPINSKY, A. C. The Relationship Between Cell Phone Use and Academic Performance in a Sample of U.S. College Students. SAGEOpen, v. 5, Feb.-Mar., 2015. Disponível em: https://journals.sagepub.com/ doi/full/10.1177/2158244015573169. Acesso em: 25 ago. 2019.

MCCOY, B. M. Digital distractions in the classroom: fase ii: student classroom use of digital devices for non-class related purpose. Journal of Media Education/BEA. Nebraska, Jan. 2016. Disponível em: https://en.calameo.com/ read/00009178915b8f5b352ba. Acesso em: 26 ago. 2019.

NÚCLEO DA INFORMAÇÃO E COORDENAÇÃO DO PONTO BR. Pesquisa sobre o uso da internet por crianças e adolescentes no brasil - TIC Crianças 2009. Coord. Alexandre F. Barbosa. São Paulo: Comitê Gestor da Internet no Brasil, 2010. Disponível em: https:/www.cetic.br/media/docs/publicacoes/2/ticcriancas-2009.pdf. Acesso em: 10 set. 2019.

NÚCLEO DA INFORMAÇÃO E COORDENAÇÃO DO PONTO BR. Pesquisa Sobre o Uso da Internet por Crianças e Adolescentes no Brasil - TIC Crianças 2010. Coord. Alexandre F. Barbosa. São Paulo: Comitê Gestor da Internet no Brasil, 2011. Disponível em: https://www.cetic.br/media/docs/publicacoes/2/ticcriancas-2010.pdf. Acesso em: 10 set. 2019.

NÚCLEO DA INFORMAÇÃO E COORDENAÇÃO DO PONTO BR. Pesquisa Sobre o Uso da Internet por Crianças e Adolescentes no Brasil - TIC Kids Online Brasil 2012. Coord. Alexandre F. Barbosa. São Paulo: Comitê Gestor da Internet no Brasil, 2013. Disponível em: https://www.cetic.br/media/docs/ publicacoes/2/tic-kids-online-2012.pdf. Acesso em: 10 set. 2019.

NÚCLEO DA INFORMAÇÃO E COORDENAÇÃO DO PONTO BR. Pesquisa Sobre o Uso da Internet por Crianças e Adolescentes no Brasil - TIC Kids Online Brasil 2013. Coord. Alexandre F. Barbosa. São Paulo: Comitê Gestor 
da Internet no Brasil, 2014. Disponível em: https:/www.cetic.br/media/docs/ publicacoes/2/tic-kids-online-2013.pdf. Acesso em: 10 set. 2019.

NÚCLEO DA INFORMAÇÃO E COORDENAÇÃO DO PONTO BR. Pesquisa Sobre o Uso da Internet por Crianças e Adolescentes no Brasil - TIC Kids Online Brasil 2014. Coord. Alexandre F. Barbosa. São Paulo: Comitê Gestor da Internet no Brasil, 2015. Disponível em: https:/www.cetic.br/media/docs/ publicacoes/2/TIC_Kids_2014_livro_eletronico.pdf. Acesso em: 10 set. 2019.

NÚCLEO DA INFORMAÇĀO E COORDENAÇÃO DO PONTO BR. Pesquisa Sobre o Uso da Internet por Crianças e Adolescentes no Brasil - TIC Kids Online Brasil 2015. Coord. Alexandre F. Barbosa. São Paulo: Comitê Gestor da Internet no Brasil, 2016. Disponível em: https:/www.cetic.br/media/docs/ publicacoes/2/TIC_Kids_2015_LIVRO_ELETRONICO.pdf. Acesso em: 10 set. 2019.

NÚCLEO DA INFORMAÇÃO E COORDENAÇÃO DO PONTO BR. Pesquisa Sobre o Uso da Internet por Crianças e Adolescentes no Brasil - TIC Kids Online Brasil 2016. Coord. Alexandre F. Barbosa. São Paulo: Comitê Gestor da Internet no Brasil, 2017. Disponível em: https://www.cetic.br/media/docs/ publicacoes/2/TIC_KIDS_ONLINE_2016_LivroEletronico.pdf. Acesso em: 10 set. 2019.

NÚCLEO DA INFORMAÇÃO E COORDENAÇÃO DO PONTO BR. Pesquisa Sobre o Uso da Internet por Crianças e Adolescentes no Brasil - TIC Kids Online Brasil 2017. Coord. Alexandre F. Barbosa. Sáo Paulo: Comitê Gestor da Internet no Brasil, 2018. Disponível em: https:/www.cetic.br/media/docs/ publicacoes/2/tic_kids_online_2017_livro_eletronico.pdf. Acesso em: 10 set. 2019.

NÚCLEO DA INFORMAÇÃO E COORDENAÇÃO DO PONTO BR. Pesquisa Sobre o Uso da Internet por Crianças e Adolescentes no Brasil - TIC Kids Online Brasil 2018. Coord. Alexandre F. Barbosa. São Paulo: Comitê Gestor da Internet no Brasil, 2019. Disponível em: https://www.cetic.br/media/docs/ publicacoes/216370220191105/tic_kids_online_2018_livro_eletronico.pdf. Acesso em: 6 nov. 2019.

RAVIZZA, S. M.; HAMBRICK, D. Z; FENN, K. M. Non-academic internet use in the classroom is negatively related to classroom learning regardless of intellectual ability. Computers \& Education, v. 78, p. 109-114, sep. 2014. Disponível em: https://www.deepdyve.com/lp/elsevier/non-academic-internet-use-in-the- 
classroom-is-negatively-related-to-ZNZuRW651M. Acesso em: 12 abr. 2016.

RAVIZZA, S. M.; UITVLUGT, M. G; FENN, K. M. Logged in and zoned out: how laptop internet use relates to classroom learning. Psychological Science, v. 28, p. 171-180, dec. 2016. Disponível em: https://journals.sagepub.com/doi/ full/10.1177/0956797616677314. Acesso em: 25 ago. 2019.

ROCHA, A. J. S.; HAAS, C. M. Como estudantes do primeiro período do direito gerem seu tempo? Uma interpretação a partir da tríade do tempo de Christian Barbosa. In: Políticas públicas na educação brasileira: avanços, limites e contradiçóes. v. 12. Ponta Grossa: Atena, 2018. Disponível em: https://www.atenaeditora. com.br/wp-content/uploads/2018/04/E-book-PP-Avan\%C3\%A7os-Limites-eContradi\%C3\%A7\%C3\%B5es.pdf. Acesso em: 25 ago. 2019.

SALES, L. M. M.; BEZERRA, M. Q. M. Os avanços tecnológicos do século XXI e o desenvolvimento de habilidades necessárias ao profissional do Direito a partir das abordagens das Universidades de Harvard e Stanford. Pensar - Revista de Ciências Jurídicas, Fortaleza, v. 23, n. 4, p. 1-13, 2018.

SEVERINO, A. J. Metodologia do trabalho científico. 23. ed. São Paulo: Cortez, 2010 .

TWENGE, J. M. IGen: por que as crianças superconectadas de hoje estão crescendo menos rebeldes, mais tolerantes, menos felizes e completamente despreparadas para a idade adulta. Tradução Thais Costa. São Paulo: nVersos, 2018.

WE ARE SOCIAL; HOOTSUITE. Digital 2019: Brazil. All the data and trends you need to understand, Internet, social media, mobile, and e-commerce behaviours in 2019. Disponível em: https://datareportal.com/reports/digital2019-brazil. Acesso em: 14 abr. 2019.

WORLD ECONOMIC FORUM. The future of jobs report 2018. September in 2018. Disponível em: https://www.weforum.org/reports/the-future-of-jobsreport-2018. Acesso em: 6 jul. 2019.

WORLD ECONOMIC FORUM. The future of jobs report 2016. January in 2016. Disponível em: http://www3.weforum.org/docs/WEF_Future_of_Jobs. pdf. Acesso em: 7 jul. 2019. 